\title{
Chapter 14 \\ Atmospheric Chemical Loadings \\ in the High Mountain: Current Forcing \\ and Legacy Pollution
}

\author{
Lluís Camarero
}

\begin{abstract}
Human emissions have changed the chemistry of atmosphere. Potentially toxic chemicals have been spread, and the global cycles of some key elements have been disrupted. Because enhanced atmospheric precipitation and cold trapping caused by elevation, high mountain ecosystems are considered as regional convergence areas of atmospheric pollutants. In this chapter, research on surface waters acidification, pollution by trace elements, and atmospheric nutrient inputs in the Pyrenees is reviewed. Pyrenean lakes have experienced only a moderate acidification, due partly to an also moderate acid load and partly to the neutralising cations carried by dust. Presently, declining concentrations of sulphate in lakes indicate that recovery is proceeding. Pollution by trace elements dates more than two millennia back. The primary accumulation sites are the sediments of lakes. Soils also hold an important burden, and there is evidence that some elements are being currently remobilised. This is causing a delayed pollution, despite deposition of several trace metals is declining. The emissions of artificial reactive nitrogen have caused increased deposition on the Pyrenean catchments, which are thus nitrogen saturated. A parallel increase of phosphorus deposition has occurred, likely caused by climatic reasons. The combined effect of both seems to be an enhanced uptake of nitrogen by phytoplankton causing a lower nitrogen concentration in lakes and a possible shift from phosphorus-to-nitrogen limitation of phytoplankton growth, as well as an incipient eutrophication. All these are examples of impacts in remote natural areas that require a global strategy of conservation beyond the boundaries of the ecosystems affected.
\end{abstract}

Keywords Atmospheric pollutants - Global biogeochemical cycles • Acidification - Trace elements - Legacy pollution - Airborne nutrients

L. Camarero $(\varangle)$

Centre d'Estudis Avançats de Blanes, CSIC, Accés Cala Sant Francesc 14, 17300 Blanes,

Girona, Spain

e-mail: camarero@ceab.csic.es

(C) The Author(s) 2017

J. Catalan et al. (eds.), High Mountain Conservation in a Changing World,

Advances in Global Change Research 62, DOI 10.1007/978-3-319-55982-7_14 


\subsection{Introduction}

One of the main impacts of human activities on the global ecosystem is the change caused on the chemistry of the atmosphere. Such a change is due mainly to the emission of a wide range of chemicals, in the form of both gases and aerosols. Some of them are potentially toxic (such as some trace metals and persistent organic molecules) and are considered as pollutants. In many cases, these pollutants do not exist in nature. Some of the emitted chemicals are present in nature, but the human emissions have caused their levels in the atmosphere to exceed by far the natural ones. This excess causes a disturbance in the planetary biogeochemical cycles, very often with awkward effects. Sometimes there is a biogeochemical bottleneck that causes the accumulation of a compound. An example of this is the rising atmospheric $\mathrm{CO}_{2}$ (and other greenhouse gases) level, now very widely accepted to be responsible of the human contribution to the global warming. In some other cases, the addition of an element causes the acceleration of the natural cycling. For instance, the introduction of large amounts of some compounds of nitrogen and phosphorus (both are major nutrients for the living organisms) in the environment has caused a nutrient imbalance in the ecosystems. This is of special importance in nutrient-poor systems, such as remote oceanic areas and high mountains, where the atmospheric inputs may have a fertilising effect that leads to an unnatural growth of primary producers, basically plants and algae.

In addition to the emissions, human activities have also the effect of modifying the natural atmospheric transport of substances. A direct way to do so is by changes in the land use; for instance, agricultural practices and deforestation may enhance production of dust and aeolian transport from land; changes in the wild fires regime affect the emission of ashes and gases from burning biomass. But there are also indirect ways that have to do with climate change, although in this case both natural and human-induced causes play a role: droughts and losses of snow cover that enhance dust production; melting of organic permafrost that increases $\mathrm{CO}_{2}$ and methane emissions from soil; changes in the prevailing winds and patterns of circulation of air masses that carry airborne substances. All these are examples of effects of climate change on the natural atmospheric fluxes of chemicals.

The long-range transport of atmospheric chemicals takes place in the free atmosphere, that is, above the mixing boundary layer which generally has a depth of $1,000-1,500 \mathrm{~m}$. In this sense, the chemistry of the free atmosphere can be considered to reflect the composition of the global atmosphere better than the boundary layer below it. High mountains protrude above the boundary layer on the lowlands around them, and thus intercept the "global" flux of chemicals. Such interception is enhanced by altitude. Orographic precipitation is higher in the mountains causing greater scavenging of airborne substances than in the lowlands. Also, temperature is lower in the summits than in the piedmont and the deposition of volatile compounds by condensation (cold trapping) is favoured. In summary, mountains act as regional (or even global) convergence areas of atmospheric chemical fluxes. 
Alpine ecosystems are sensitive to the atmospheric inputs for several reasons. They are headwater catchments where chemical weathering of the bedrock is limited, specially in those on highly insoluble crystalline rocks, so lake and stream waters are very diluted. Consequently their capacity of buffering any acidity coming with precipitation is rather poor. Nutrients coming from the substrate are also scarce. Therefore, the atmospheric supply is an important (if not the larger) fraction of nutrient input to alpine ecosystems. Catchment soils and lake sediments are generally highly organic. This gives them a large capacity for binding pollutants such as trace metals and organic chemicals. In the long run, this great affinity causes a build-up of the pollutant burden stored in soils and sediments. These are some of the main reasons for the sensitivity of alpine systems to atmospheric chemical loadings. They are sensitive in two senses. First, they are actually threatened by certain atmospherically deposited chemicals that may reach levels that have ecotoxic effects or alter the natural ecosystem functioning, and constitute a conservation issue. But second, even in the cases where impacts are not severe, the signs of the chemical inputs are easily noticeable. Inputs that, remember, respond to a global forcing. This makes alpine ecosystems an excellent early warning system of global environmental change.

In this chapter, I am mostly presenting a summary of the results regarding some of the topics mentioned above obtained during almost 30 years of research in the Pyrenees. But beyond the local interest, the results presented here are an example of how atmospheric chemical loadings affect high mountains that also applies to other high mountain ranges.

\subsection{Surface Waters Acidification}

Since the onset of the Industrial Revolution, the massive burning of fossil fuels has caused the emission of sulphur and nitrogen oxides to the atmosphere. These oxides acidify the atmospheric precipitation, as it was already noticed in the mid-nineteenth century when the term "acid rain" was coined (Smith 1872). Acid rain in its turn acidifies soils and surface waters when these receptor systems cannot buffer the incoming acidity. In that case, deleterious effects occur. The first cases of environmental damage caused by acid deposition were reported at the beginning of the twentieth century. These first cases were attributed to local sources in the vicinities of the impacted sites (Cowling 1982). But in the 1970s the effects of long-range transport of pollutants shifted the focus to a larger scale. There was then widespread evidence of regional acidification of surface water, affecting the most sensitive lacustrine areas in the Northern Hemisphere: the Precambrian Shields of Canada and Scandinavia (Gorham et al. 1986; Odén and Ahl 1979; Likens and Bormann 1974). During the 1980s, on the basis of the scientific studies carried out in the previous years, it was generally accepted that human emissions were producing significant acidification of fresh waters (Schindler et al. 1985) and might be a factor contributing to forest dieback (Pitelka and Raynal 1989) on a regional scale. 
Sulphate derived from the sulphur oxide emissions was identified as the main acidifying agent (Neary and Dillon 1988; Sullivan et al. 1988). As a consequence of the overwhelming evidence, serious efforts were made to control the sulphur emissions. Laws aiming to the reduction of emissions came into force in Europe and North America (UNECE 2016a). Recovery of acidified ecosystems did not follow the reduced emissions immediately. There is a hysteresis in the reversal of acidification. However, there is nowadays growing evidence that recovery is in progress, although there are also some uncertainties about how it will be in the next future (Wright et al. 2005). There are for instance confounding factors related to climate change that can mask or counteract the recovery, such as increase of $p \mathrm{CO}_{2}$ and organic acids in soil and runoff and increased sea salt atmospheric inputs. (Wright et al. 2006). Furthermore, the global emissions of sulphur may rise again as emerging economic powers develop their industry (Streets and Waldhoff 2000; Smith et al. 2011).

As mentioned above, high mountain environments and, in particular, surface waters lying on crystalline bedrocks are sensitive to acidification. The sensitivity of lakes, for instance, can be assessed according to the acid neutralising capacity (ANC) of its waters. ANC is a chemical parameter that measures the difference between dissolved base cations and acid anions. ANC is expressed in terms of equivalents (the usual unit for diluted waters is $\mu \mathrm{eq} \mathrm{L}^{-1}$ ). ANC is closely related to $\mathrm{pH}$. Negative ANC values indicate acidic lakes, with $\mathrm{pH}$ below 5.5. Organisms able to survive below that $\mathrm{pH}$ are an exception. In the Pyrenees, c. $2 \%$ of lakes have negative ANC. Lakes with ANC between 0 and $50 \mu \mathrm{eq} \mathrm{L}^{-1}$ have a $\mathrm{pH}$ in the range 5.5-6.5. Many organisms are affected in some degree by acidity in this range of $\mathrm{pH}$. Furthermore, the buffering capacity is so low that small additions of acid may lead to negative ANC values. Approximately $15 \%$ of Pyrenean lakes lie in this range of ANC and $\mathrm{pH}$. $\mathrm{pH}$ above 6.5 do not cause particular damage to organisms. Nevertheless, lakes with ANC $<200 \mu \mathrm{eq} \mathrm{L}^{-1}$ are susceptible to reach seasonally low $\mathrm{pH}$ values as, for instance, during snowmelt runoff in spring. For this reason, lakes below $200 \mu \mathrm{eq} \mathrm{L}^{-1}$ are considered potentially sensitive to acidification. In the Pyrenees, c. $44 \%$ of lakes falls in the range of ANC between 50 and $200 \mu \mathrm{eq} \mathrm{L}{ }^{-1}$. Altogether, about $60 \%$ of Pyrenean lakes are, in higher or lower degree, sensitive to acidification.

How has acidification evolved in the Pyrenean lakes? Modelling on the basis of reconstructed acid deposition and the current chemical features of lakes indicates that the effects of acidification have been moderate in the Pyrenees (Camarero and Catalan 1998). The modelling results indicate that Pyrenean lakes have experienced an ANC loss of c. $35 \mu \mathrm{eq} \mathrm{L} \mathrm{L}^{-1}$ on average since 1850 . This has caused only $2 \%$ of lakes to cross the boundary of $\mathrm{ANC}=20 \mu \mathrm{eq} \mathrm{L} \mathrm{L}^{-1}$ (the lower limit for salmonids survival), low in comparison with the $25 \%$ in many areas of Central and Northern Europe and the $90 \%$ in the most sensitive areas of Scandinavia. The reasons for this are, on the one hand, that the atmospheric acid load has been lower on the Pyrenees than on the more polluted Central and Northern Europe and, on the other hand, that dust inputs from the Iberian Peninsula and Northern Africa are important here. Dust is a large source of base cations able to neutralise acidity in precipitation and to 

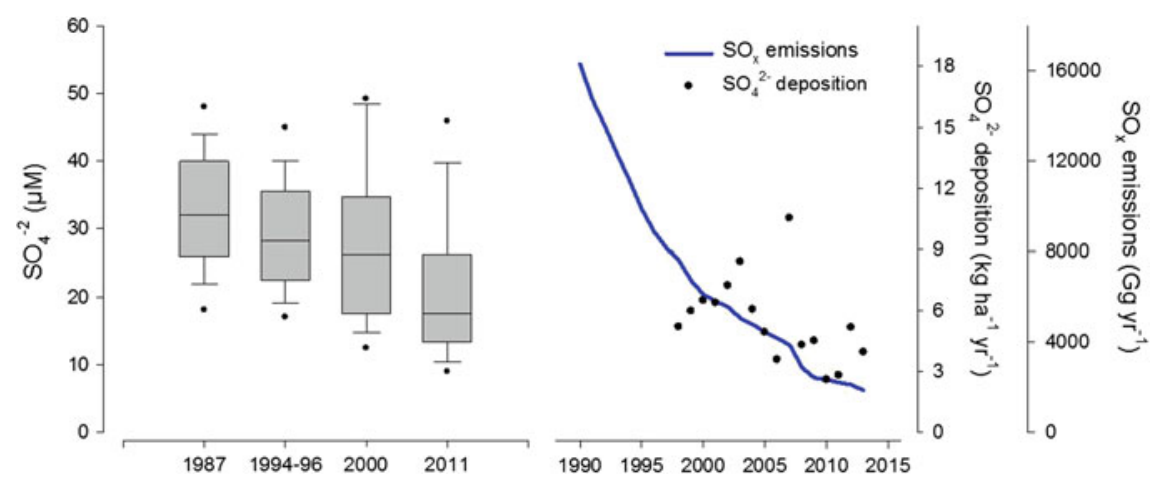

Fig. 14.1 Left Box plot showing the distribution of sulphate concentration in Pyrenean lakes on igneous bedrock, where there is no supply of sulphur from rock weathering. Each box corresponds to a synoptic survey carried during the summer of the years indicated in the axis. The line within the box represents the median value, limits of the box are the 25th and 75th percentiles, whiskers are the 10th and 90th percentiles and dots are the 5th and 95th percentiles. Right Trend-line showing the evolution of $\mathrm{SO}_{\mathrm{x}}$ emissions to the atmosphere in Western Europe since 1990 (Source EMEP http://www.ceip.at/ms/ceip_home1/ceip_home/webdab_emepdatabase/emissions_ emepmodels/). The overimposed dots represent yearly sulphate deposition as measured at the Lake Redon sampling station (Central Pyrenees). All three series show a clear decreasing trend

confer ANC to the receiving waters (Psenner 1999). Measurements of the chemical composition of precipitation show that wet air masses coming from southern locations exhibit higher concentration of base cations than those originated in northern areas (Camarero and Catalan 1996).

What is the present-day situation regarding acidification in the Pyrenees? Sulphate deposition has been decreasing since the 1980s, in good agreement with the reduction in sulphur emissions to the atmosphere since then. Lakes are also responding to that, with decreasing sulphate concentrations in lakes on non-sulphur containing bedrocks (Fig. 14.1). The lakes of the Pyrenees are thus useful witnesses of the recovery of surface waters from acidification, even if acidification has not been here as extreme as in other locations.

\subsection{Trace Elements Pollution}

Acidification was the first case of pollution that raised general concern about the effects of long-range transported pollutants on distant ecosystems. But it is not the oldest case of large scale pollution. Contamination by trace elements started more than two millennia ago.

The term "trace elements" is progressively substituting the formerly used term "heavy metals"; not all elements included in the term are metals, nor heavy. Trace elements include metals, metalloids and organometals that are potentially toxic to biota when found at concentrations higher than the ones usually observed within 
organisms. In organisms, trace elements are truly found at the level of traces. But they can be present at much higher levels in the environment surrounding those organisms. Lead is one of such trace elements. A widespread contamination by lead over the Northern Hemisphere is the oldest large-scale known pollution caused by human industry (Nriagu 1996). It dates back to the discovery of cupellation (a metallurgical process for refining noble metals) 5,000 years ago, although it increased largely 2,600 years ago with the introduction of coinage during the Ancient Greek and Roman times. Smelting of metal ores in open fires caused the emission of substantial amounts of lead and other metals to the atmosphere. After the decline of the Roman Empire, a second pulse of lead pollution was caused by the exploitation of silver mines in Central Europe during the Middle Age. A third one occurred in modern times, starting with the Industrial Revolution during the nineteenth century and peaking with the great expansion of motor vehicle traffic since the end of the Second World War, in the period in which leaded gasoline was used. Acute lead poisoning is known since the Ancient times, but it was not until the 1960s and early 1970s that studies presented evidence that chronic exposure to relatively low lead levels in the environment were causing neurological impairment in subjects, especially children, with no clinical symptoms of toxicity (Needleman 2004). This finding was crucial to the banning of lead in gasoline (and also in paint for domestic use) in the 1980s. Currently, there are international agreements to further reduce emissions of lead and some other trace elements to the atmosphere (UNECE 2016b).

The Pyrenees have not escaped pollution by trace elements. The sediments from the lakes are a record of the history of pollution in the Pyrenees; changes in the concentration of trace elements in layers of sediment deposited at different moments reveal what was the contamination load at each time. Thus, for instance, the analysis of sediments from Lake Redon (42 $38^{\prime} \mathrm{N}, 0^{\circ} 46^{\prime} \mathrm{E} ; 2240 \mathrm{~m}$ a.s.1.) in the Central Pyrenees (Fig. 14.2) showed increasing levels of contaminating lead since the 4th century BCE, a conspicuous peak during the ninth century CE, and a modern peak starting in 1900 (Camarero et al. 1998). Furthermore, lead isotopic composition changed in the peaks from the natural lead composition in the oldest strata towards values closer to that of lead from mining activities. This pattern likely results from the mixing of global, regional and even local influences. The onset of the rise is in good agreement with the accepted global chronology of emissions. But the tallest peaks are more reasonably attributed to mining in the surrounding areas, although in the most recent one the influence of leaded gasoline cannot be distinguished from mining and probably also contributes.

Contamination of lake sediments by lead during the past centuries, if not longer, is common in the Pyrenees. Almost with no exception, all lakes analysed show increased values of lead with an isotopic composition that reveals its polluting origin in the uppermost sediment layers (Bacardit et al. 2012). Other contaminating trace metals such as cadmium, copper, mercury, nickel and zinc are often found accompanying lead. Polluting trace elements are not equally distributed along the whole Pyrenean range. An extensive lake survey showed that modern surface sediments were enriched in lead and mercury with respect to deeper pre-industrial 


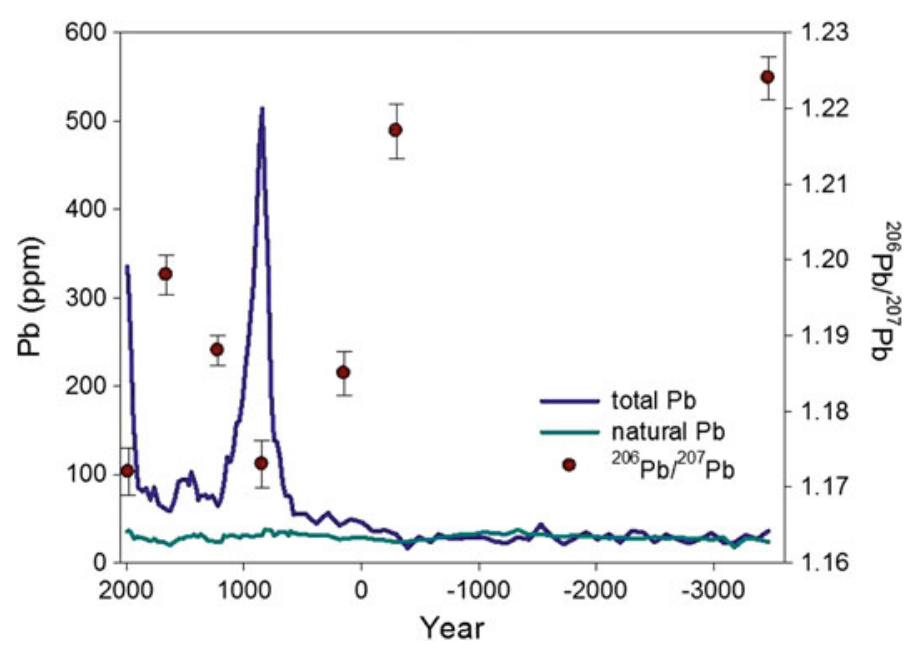

Fig. 14.2 Concentration and isotopic composition of total extractable lead in a sediment core from Lake Redon (Camarero et al. 1998). Natural lead was estimated from the aluminium concentration along the core and the natural lead-to-aluminium ratio. The difference between total and natural lead corresponds to the polluting lead inputs. Total lead consistently diverges from natural lead since c. $300 \mathrm{BCE}$, and shows two conspicuous peaks in c. $850 \mathrm{CE}$ and present. The isotopic ratio ${ }^{206} \mathrm{~Pb} / \mathrm{Pb}$ varies accordingly, from the natural value (c. 1.22) to lower values consistent with the mixing with lead coming from the nearby mines of Cierco (c. 1.18) and Bossost (c. 1.15). In the modern peak, also lead from gasoline (c. 1.04) might have some contribution

sediments, and that lakes in the Central and Eastern Pyrenees were more frequently enriched than lakes in the Western side (Camarero 2003). This difference could be hypothetically due to a higher deposition of dust from southern locations carrying those metals adsorbed onto the particles (see below) in the Centre and East.

The concentration of some trace elements in the surface sediments of a number of lakes is surprisingly high for such relatively remote sites where pollutants arrive exclusively through atmospheric deposition (Fig. 14.3). The concentration found in those lakes is comparable to the levels found in sites with intense pollution, such as areas directly affected by urban and industrial sewage discharge or within harbours (Camarero et al. 2009). Some factors likely contribute to these high levels: first, lake sediments are the final sink of many elements deposited in the whole catchment and transported from there to the lake, so it may take place a "focussing" of pollutants towards the sediments; second, sediments of Pyrenean lakes tend to be very organic and have therefore a great affinity and ability to bound metal and metalloid cations; and finally, sedimentary rates in these non-productive lakes are often very low, so the effect of "dilution" of pollutants within the bulk sediment is minimised. As a consequence, a large proportion of the lakes presents concentrations of trace elements in sediments that are above the boundary where the first toxic effects on biota are detected, or even above the level in which severe effects occur. 


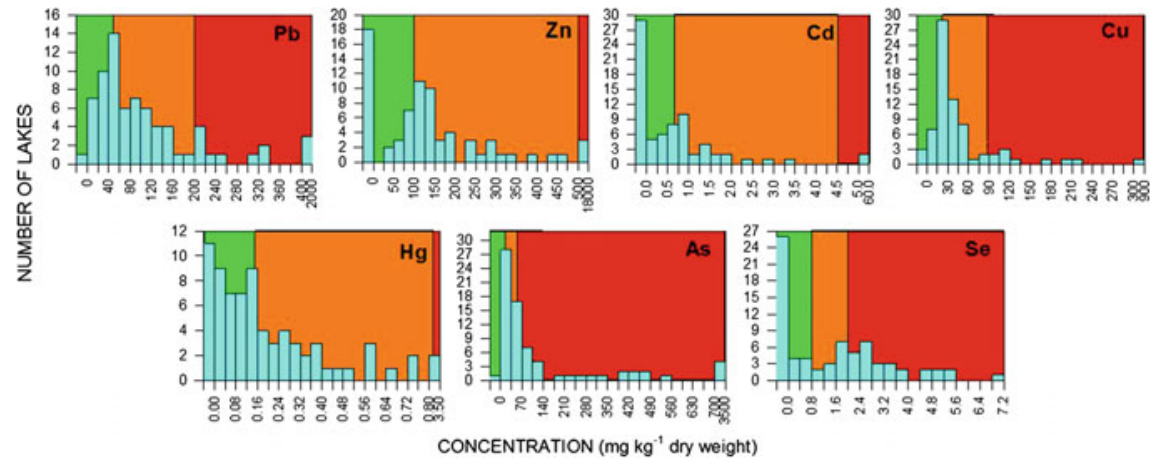

Fig. 14.3 Histograms (blue bars) showing the distribution of concentration of several trace elements in sediments from 85 Pyrenean lakes surveyed in 2000 (Camarero 2003). Background colours represent intensity of pollution, based on a worldwide review of aquatic sediments: background (green), moderate (orange) and intense (red), according to Camarero et al. (2009). The boundaries between coloured areas approximately coincide as well with the "lowest effect" (the first effects on organisms are detected) and "severe effect" (lethal effects in $>80 \%$ of organisms) limits reported from bioassays in sediments

How is presently the atmospheric deposition of trace elements at high altitude in the Pyrenees? Measurements done in the Lake Redon sampling station during the decade 2004-2013 show that the concentration in atmospheric precipitation (volume weighted average) of the most commonly monitored trace elements are in the range of nanogram per liter ( $\mathrm{ng} \mathrm{L}^{-1}$ ) but vary by three orders of magnitude, from several thousand for the most abundant to a few tens for the scarcest:

$$
\begin{aligned}
& \mathrm{Zn}\left(6500 \mathrm{ng} \mathrm{L}^{-1}\right)>\mathrm{Pb}\left(960 \mathrm{ng} \mathrm{L}^{-1}\right) \sim \mathrm{Cu}\left(950 \mathrm{ng} \mathrm{L}^{-1}\right)> \\
& >\mathrm{Ni}\left(180 \mathrm{ng} \mathrm{L}^{-1}\right)>\mathrm{As}\left(38 \mathrm{ng} \mathrm{L}^{-1}\right)>\mathrm{Cd}\left(20 \mathrm{ng} \mathrm{L}^{-1}\right)
\end{aligned}
$$

These values fall within the range of measurements in relatively remote sites in Europe, suggesting that they can be considered as background levels of pollution in atmospheric precipitation, at least in the European context.

The deposition of trace elements varies with time: it fluctuates seasonally, interannually and, in some cases, they show statistically significant decadal trends. Both interannual and seasonal variations are related with the origin of the air masses causing precipitation: air masses coming from the Iberian Peninsula and Northern Africa carry dust, and associated to it there is polluting lead, nickel and cadmium which are transported mainly bound to particles (Bacardit and Camarero 2009). Southern precipitation is more frequent during spring and summer, whereas during winter precipitation comes more often from north. This explains the seasonal fluctuation (higher values in summer) in deposition of those trace elements associated to dust. Similarly, the proportion of both types of precipitation changes from year to year, producing interannual differences in trace elements deposition. In years with a higher frequency of precipitation with a southern origin, lead, nickel and cadmium deposition is higher. In contrast, in years with higher frequency of precipitation with a northern provenance zinc and copper deposition is higher. Beyond this interannual 
variation, lead, zinc and nickel show a significant decreasing trend between 2004 and 2013, in good agreement with the reduction in the emissions to the atmosphere recorded in Europe during the same period (EEA 2013).

Is the abatement of emissions the end of the story about trace elements pollution? Possibly not. Besides lake sediments, soils are another matrix where trace elements have accumulated during centuries of contamination. The amount of polluting trace elements in high mountain soils (averaged taking into account bare rock areas) in the Pyrenees (Bacardit et al. 2012) can be quantified in milligrams per square metre $\left(\mathrm{mg} \mathrm{m}^{-2} ; \mathrm{Pb}\right.$ and $\mathrm{Zn} \sim 1000, \mathrm{Ni}$ and $\left.\mathrm{Cu} \sim 200, \mathrm{Cd} \sim 10\right)$, whereas yearly atmospheric deposition is measured as micrograms per square metre $\left(\mu \mathrm{g} \mathrm{m}^{-2} ; \mathrm{Zn} \sim 10,000, \mathrm{~Pb}\right.$ and $\left.\mathrm{Cu} \sim 1000, \mathrm{Ni} \sim 250, \mathrm{Cd} \sim 25\right)$. That is, soils hold (on a per unit area) an anthropogenic trace elements burden that is about three orders of magnitude larger than the current yearly deposition, even larger if natural (i.e. coming from the rocks) trace elements are included. So, what is the fate of this pollution legacy? May it be released from soils and contaminate the water courses, for instance? There is evidence for certain elements that this is indeed the case (Bacardit and Camarero 2010). Measurements in some Pyrenean catchments show that the amount of lead that reaches the lakes every year from the terrestrial area is larger than the lead deposited from the atmosphere on the whole catchment (Fig. 14.4). Other trace metals, such as zinc, continue to be stored within the catchments. But as shown above, zinc is deposited at a high rate, so soils could be

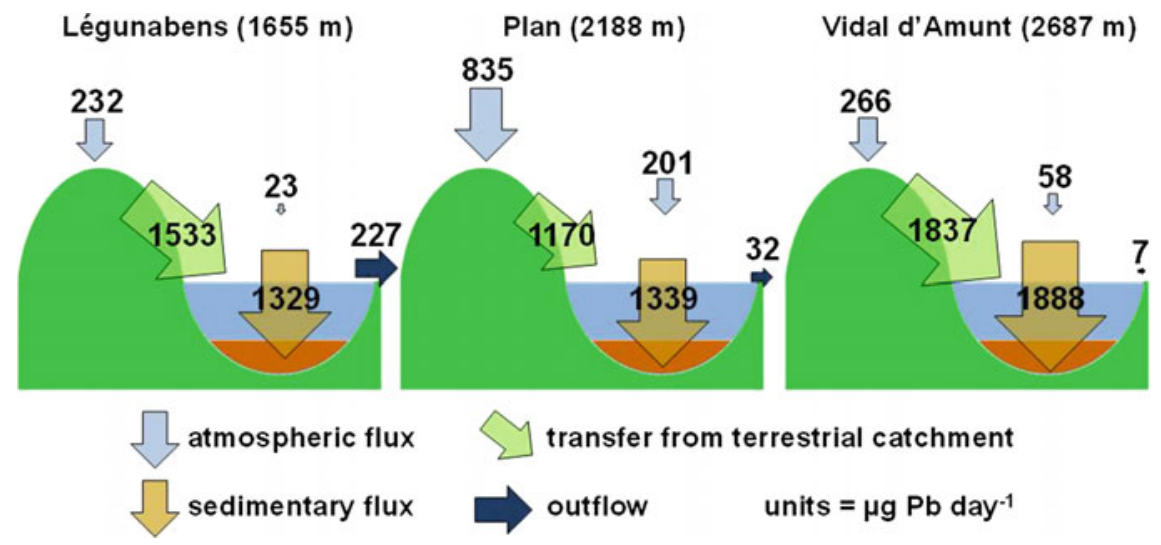

Fig. 14.4 Mass balance modelling (Bacardit and Camarero 2010) of the fluxes of lead during the snow-free season within three catchments and their lakes in the Pyrenees: Légunabens $\left(42^{\circ} 45^{\prime} \mathrm{N}\right.$, $\left.1^{\circ} 26^{\prime} \mathrm{E}\right)$, Plan $\left(42^{\circ} 37^{\prime} \mathrm{N}, 0^{\circ} 56^{\prime} \mathrm{E}\right)$ and Vidal d'Amunt $\left(42^{\circ} 32^{\prime} \mathrm{N}, 0^{\circ} 60^{\prime} \mathrm{E}\right)$. The atmospheric flux was measured using precipitation collectors, and it is split between direct deposition onto the lake and the terrestrial catchment according to their respective surface areas. Sedimentary fluxes were measured using sediment traps deployed in the deepest part of the lake. Outflow was calculated from discharge and lead concentration in the epilimnetic water. Transfer of lead from the terrestrial catchment to the lake was estimated so as to balance the mass fluxes. Arrows size is proportional to the computed fluxes. The main result is that the transfer of lead from the catchment to the lake is in all cases larger than the atmospheric flux. This indicates that the catchment is a net source releasing lead that was previously stored in soils 
eventually saturated and start to release it (Nriagu et al. 1998). And climate change may have a synergistic effect (Klaminder et al. 2010). It has been argued that climate change-related processes, such as intensification of soil carbon mineralisation, melting of permafrost and increased erosion, may accelerate the shift of soils from sink to source.

\subsection{Effects of Airborne Nutrients on Ecosystems}

Pollutants are not the only substances transported atmospherically. Some airborne substances can provide important elements for life; in this case they are considered nutrients. Nitrogen and phosphorus are of particular interest. Both are key limiting nutrients in ecosystems, and their relative availability determines ecosystem productivity and species composition. Human activities have altered the global cycles of $\mathrm{N}$ and $\mathrm{P}$, leading to an increased flux of these elements through the atmosphere.

There is plenty of $\mathrm{N}$ in the earth's atmosphere, but it is the form of inert gas generally unavailable for organisms. Organisms need the so called reactive nitrogen, that is, nitrogen-bearing molecules that can be assimilated by primary producers. These molecules are principally nitrate and ammonium. The natural production of reactive nitrogen is low, causing the productivity of many ecosystems to be limited by nitrogen. But since the start of industrialisation, human production of reactive nitrogen has increased dramatically by artificial nitrogen fixation and the use of internal combustion engines (Elser 2011). Artificial nitrogen fixation is an industrial process (Haber-Bosch process) that converts gaseous nitrogen into ammonia, which can be oxidised afterwards to produce nitrite and nitrate. The process has been massively used to produce fertilisers for agriculture, and the increased use of artificial fertilisers has lead in turn to higher emissions of ammonia to the atmosphere from soils and livestock, as well as dust rich in nitrogen from the field crops. In parallel, the use of internal combustion engines in automobiles mainly, but also other industrial combustion processes, have generalised the burning of fossil fuel causing huge emissions of nitrogen oxides to the atmosphere. Nitrogen oxides are precursors of nitrate, which has an acidifying effect but is also a nutrient. As a consequence of all these increased emissions, atmospheric transport and subsequent deposition has become the dominant distribution process of reactive nitrogen on a global basis (Galloway et al. 2008), and nitrogen deposition to ecosystems has increased from $\sim 0.5$ kilograms per hectare and year $\left(\mathrm{kg} \mathrm{N} \mathrm{ha}^{-1}\right.$ year $^{-1}$ ) or less in pristine conditions to rates that are nowadays greater than one order of magnitude, exceeding $10 \mathrm{~kg} \mathrm{~N}^{-1} \mathrm{year}^{-1}$ on average in large areas of the world. Similarly to the case of sulphur oxides, efforts are underway to abate the nitrogen oxides emissions in Europe and North America, but emissions from emerging economies demanding more energy may counteract these reductions on a global balance. Furthermore, the production of reactive nitrogen related with agriculture is about $75 \%$ of the total, and it is challenging to reduce it in a world where hundreds of millions of people still suffer from a "fertilizer deficit". And the 
increased use of biofuels from crops that need to be fertilised with nitrogen adds a new dimension to the problem. Predictions are that reactive nitrogen deposition may double by 2050 , with some regions reaching $50 \mathrm{~kg} \mathrm{~N} \mathrm{ha}^{-1}$ year $^{-1}$ (Galloway et al. 2004).

Nitrogen deposition has been measured routinely in many places since it was recognised as an acidifying agent. In contrast, phosphorus deposition measurements are much less frequent and, as a matter of fact, the knowledge about the atmospheric phosphorus cycling is limited. In the absence of measurements, most of our present understanding derives from modelling, which is based on the estimation of emissions coupled with models of atmospheric circulation to infer the transport and distribution of atmospheric phosphorus. Phosphorus does not form easily gases that can be emitted, so it has been assumed that it is mainly transported as particles. Under this assumption, the estimations indicate that, on a global basis, most (>80\%) of the atmospheric phosphorus is in mineral aerosols, with primary biogenic particles and combustion particles having a weight only in non-dusty regions (Mahowald et al. 2008). They also indicate that atmospheric phosphorus of human origin is only $5 \%$ of the total. However, recent work suggests that gaseous phosphorus emissions are important during combustion processes. If gases are also considered, human atmospheric phosphorus should then account for about $50 \%$ of the total (Wang et al. 2015). Estimates are therefore still controversial, and this fact highlights the need of a better understanding of the processes of production and speciation of atmospheric phosphorus. In any case, human action may have an strong effect on the atmospheric phosphorus balance, either by enhancing mineral dust production by land-use changes and (indirectly) climate change, or by increasing combustion sources, or both. Although global trends are not clear (mainly because of the lack of data), some research suggests that a significant increase in phosphorus deposition has occurred since pre-industrial times, and that this increase can be causing a change in the biogeochemistry and the trophic status of naturally oligotrophic systems, such as alpine lakes (Brahney et al. 2015). The same can be claimed for nitrogen. Yet phosphorus is present as a constituent of living matter in a lower proportion than nitrogen. Hence, for stoichiometric reasons, smaller changes in phosphorus than nitrogen availability may potentially have a larger effect on primary production. It is therefore necessary to take both nutrients into account in order to assess their true impact.

The nitrate concentrations in streams indicate that the Pyrenean catchments are saturated with nitrogen. The concept of nitrogen saturation means that the catchment is receiving more nitrogen than organisms (plants and microbiota) living in the catchment are able to take up and immobilise, so a part of it is leached out of the catchment, mostly as nitrate in running waters. Nitrate concentrations in the Central Pyrenees streams fluctuate seasonally, with basal values typically between 7 and $10 \mu \mathrm{eq} \mathrm{L}^{-1}$ during the plant growing season and peaks as high as $20-30 \mu \mathrm{eq} \mathrm{L} \mathrm{L}^{-1}$ during the dormant period. On a scale from 0 to 3 (Stoddard and Traaen 1995), Pyrenean catchments are at saturation stage 2, defined as "saturated, with high N loss".

The atmospheric nitrogen load from bulk deposition (deposition with rain and the fine fraction of dry deposition) in the central Pyrenees in 2010 was c. $10 \mathrm{~kg} \mathrm{~N} \mathrm{ha}{ }^{-1}$ 
year $^{-1}$, matching the global average. This deposition rate has been increasing during the precedent decade, in good agreement with the Spanish inventory of nitrogen emissions; but, surprisingly, the lakes in the Pyrenees did not follow the same trend (Fig. 14.5). In an opposite way, the concentration of dissolved inorganic nitrogen has decreased with time in the lakes (Camarero and Catalan 2012).

Why is nitrogen concentration declining in the lakes? Monitoring data from Lake Redon provide insight into the process that causes this (Fig. 14.6). While nitrogen deposition and nitrogen concentration in Conangles creek (a stream which drains the Lake Redon basin together with a much larger area without lakes) have increased, nitrogen in the lake has been decreasing, in agreement with the trend observed for the whole set of studied lakes. The most plausible reason is that the uptake of nitrogen by primary producers has increased at a higher rate than nitrogen deposition, an increase that might be explained by the fact that phosphorus deposition has increased in parallel to nitrogen deposition. This may be causing a shift from a situation in which phosphorus was the limiting nutrient, so nitrogen in excess of biological needs can accumulate, to a new situation in which this limitation is alleviated by the increased input of atmospheric phosphorus, so more nitrogen is consumed to the point of becoming limiting and, eventually, exhausted. Presumably, limitation by phosphorus is a circumstance that has been induced by the increased deposition of reactive nitrogen of human origin during industrialisation (Goldman 1988). This new change towards nitrogen limitation can be seen as a return to a pristine situation. However, there is a difference. The inputs of both

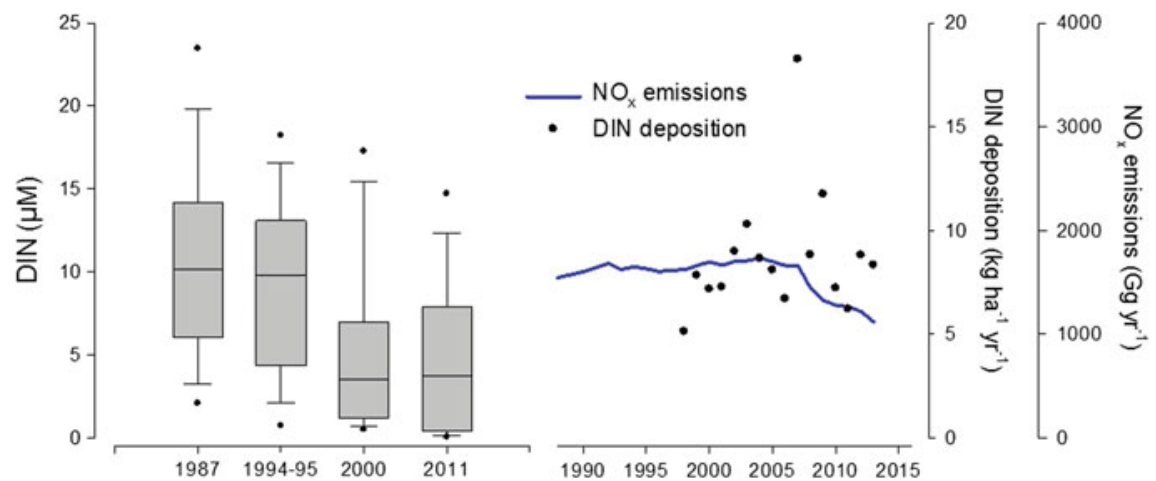

Fig. 14.5 Left Box plot showing the distribution of dissolved inorganic nitrogen (DIN) concentration in Pyrenean lakes (percentiles represented as in Fig. 14.1) during four synoptic surveys (Camarero and Catalan 2012). Right trend-line showing the evolution of $\mathrm{NO}_{\mathrm{x}}$ emissions in Spain (Source EMEP, http://www.ceip.at/ms/ceip_home1/ceip_home/webdab_ emepdatabase/emissions_emepmodels/) The overimposed dots represent yearly DIN deposition as measured at the Lake Redon station. While DIN concentration has decreased since the late 1980s, emission presented an increasing trend up to 2007. From then on, a sharp decrease is reported, likely caused by the application of more stringent measures of reduction and also as an effect of the economic crisis. Deposition of DIN does not show a clear response to that sharp decrease. Up to the year 2009 deposition increased. Only from 2010 on an incipient downward trend could be argued, but it does not seem to be proportional to the reduction in emissions 
(a)

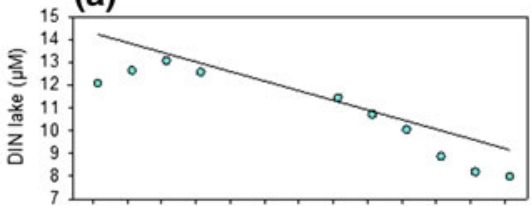

(b)

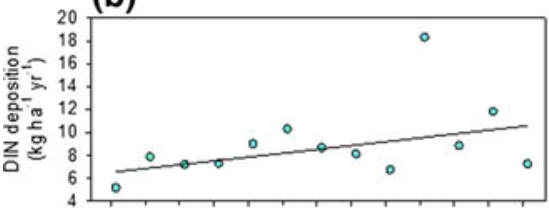

(c)

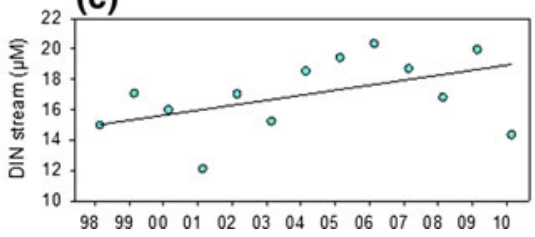

(d)

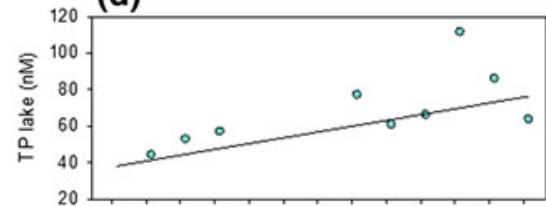

(e)

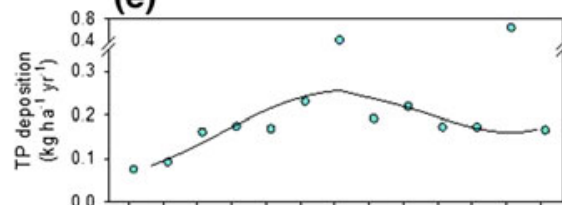

(f)

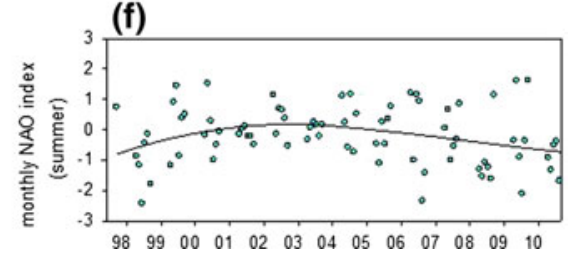

Fig. 14.6 Panels a-e show nitrogen and phosphorus in Lake Redon and its catchment (Conangles). a DIN concentration in lake water (yearly average); b DIN yearly deposition; c DIN concentration in stream water (Conangles creek, yearly average); $\mathbf{d}$ total phosphorus in lake water (yearly average); e total phosphorus yearly deposition. Panel $\mathbf{f}$ shows the values for the monthly NAO index during spring and summer (April-September). While nitrogen deposition has increased, DIN in the lake has decreased. The increase in the stream indicates that the catchment is not a sink for nitrogen. Therefore, an in-lake process should control DIN in the lake. Phosphorus has increased both in deposition and in the lake, suggesting a fertilisation effect that has enhanced nitrogen uptake. The stoichiometry of the lake has shifted towards a hypothetical situation of nitrogen limitation for phytoplankton. Both phosphorus deposition and the NAO index show a bell-shaped trend. A higher frequency of positive NAO values in the mid part of the period likely correlates with more frequent dust outbreak episodes carrying phosphorus from Northern Africa to the Pyrenees. This would indicate a certain meteorological control on the transport of atmospheric phosphorus (after Camarero and Catalan 2012)

nutrients are higher now, so the productivity of the ecosystem seems to be enhanced (Fig. 14.7) and we can speak of a change in the trophic status of the Pyrenean lakes towards a relative (in terms of these low-productive waters) "eutrophication".

Phosphorus comes largely from South, accompanying the dust outbreaks reaching the Pyrenees from Northern Africa and the Iberian Peninsula (Camarero and Catalan 2012). There is a certain correlation between the North Atlantic Oscillation (NAO) index and the production of dust in Northern Africa and subsequent transport towards the Mediterranean (Moulin et al. 1997). Positive NAO values entail dryer meteorological conditions and therefore higher dust inputs to the atmosphere. Changes in the dust and phosphorus inputs may therefore be linked to natural meteorological variations. But in the context of climate change, it can be also argued that human action is contributing indirectly to enlarge the atmospheric dust fluxes as well (Mahowald et al. 2010). The data set presented here could be 


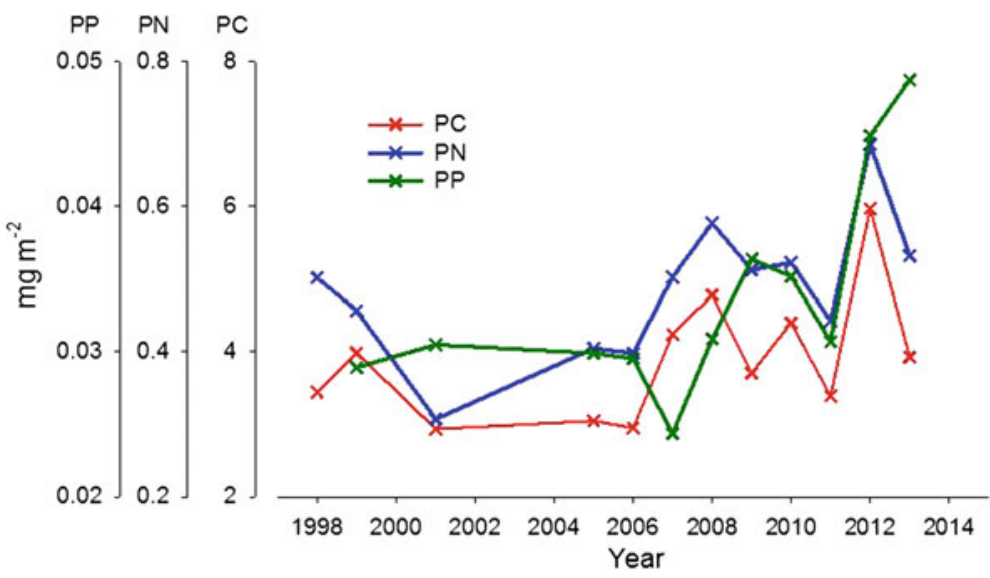

Fig. 14.7 Particulate carbon, nitrogen and phosphorus in the water column of Lake Redon, as indicators of the standing biomass of plankton (excluding crustaceans) in the lake. Values are integrated over the whole water column and are expressed on a per square metre basis. From 2007 on, planktonic biomass has increased. This could be an early indication of a shift of the lake towards a higher trophic status caused by the increase in atmospheric nitrogen and phosphorus deposition

either part of a longer trend or a mere fluctuation. But in any case, what can be deduced from it is that the anthropogenic nitrogen inputs, by causing phosphorus limitation, have made the lake more sensitive to any natural or human-induced phosphorus input than it would be otherwise. It is a combined effect of both nutrients what is causing a response of the system.

\subsection{Some Reflections on Conservation}

The issues presented here have a characteristic that prevents us from viewing them using a conventional conservation approach: they cannot be treated within the boundaries of the own ecosystems. The systems cannot be isolated from the atmosphere to protect them, and there is no way to "clean" them from the undesirable chemical load already deposited. These facts add a wider dimension to the concept of conservation: actions at a large scale, and not necessarily related or applied in a direct way to the ecosystems to be preserved, are required to protect them. Mountains are not the only example of ecosystems being at risk by a distant threat. But, at least in Europe, they are perceived as the last wilderness left untouched. This perception helps to make a strong point and raise public concern on the message that some kind of global action is required to protect those parts of nature that a priori seemed unaffected by impacts caused by humans.

The results presented here highlight some notions that are of current concern regarding the processes involved in the atmospheric transport and fate of polluting chemicals. The first notion is that they do have a fate. In contrast with an early, 
simplistic idea that chemicals emitted to the atmosphere were somehow "diluted" down to no-effect levels, i.e. virtually disappearing, research has shown that pollutants may undergo preferential accumulation. By entering the biogeochemical cycles they can be directed to some particular sites where they accumulate to reach significant concentration. This is worsened by the fact that humans have developed a capacity to mobilise chemicals in amounts comparable to (or even much higher than) the global natural fluxes. As a result, accumulated chemicals are not merely a "footprint" of human actions, but they are present in large pools in the environment. Examples of this are the accumulation of trace elements in Pyrenean lakes sediments, and the reactive nitrogen saturation exhibited by streams.

A second important notion is that these pools are a pollutant legacy that may not be the ultimate fate of contaminants. Chemicals stored over time can be remobilised and constitute a secondary source of delayed pollution. There is a legacy of pollution that span not only over space, but also over time. The export of polluting lead accumulated during millennia from catchments in the Pyrenees is an example of that.

Another important emerging idea is that there are synergistic effects caused either by several pollutants or by the interaction between pollutants and climate change. For instance, the combined effect of human nitrogen emissions together with changes in natural emissions of phosphorus-bearing dust (with a possible connection to climate changes) is changing the trophic status of Pyrenean lakes. Such combined effects add complexity to the picture. Knowledge about multi-factor synergistic and confounding effects is still missing, as well as on effects caused by long-term chronic exposure to environmental doses of multi-pollutant mixtures.

And finally, there are also findings that bring some hope. Sulphate decline in surface waters as recorded in the Pyrenees (and other sensitive areas worldwide) suggests that perhaps it is not too naive to think that global actions are still possible to preserve nature. Despite there is a hysteresis in the reversibility of acidification, and that climate change has confounding (or even counteracting) effects on it, it seems that recovery of ecosystems may proceed, provided that polluting emissions are abated and sufficient time is allowed to natural processes to act. In this sense, remote ecosystems such as high mountain catchments have a role not only as warning systems, but also as indicators to assess the effectiveness of policies and efforts for global conservation.

\section{References}

Bacardit M, Camarero L (2009) Fluxes of Al, Fe, Ti, Mn, Pb, Cd, Zn, Ni, Cu, and As in monthly bulk deposition over the Pyrenees (SW Europe): the influence of meteorology on the atmospheric component of trace element cycles and its implications for high mountain lakes. J Geophys Res 114:G00D02

Bacardit M, Camarero L (2010) Atmospherically deposited major and trace elements in the winter snowpack along a gradient of altitude in the Central Pyrenees: the seasonal record of long-range fluxes over SW Europe. Atmos Environ 44:582-595 
Bacardit M, Krachler M, Camarero L (2012) Whole-catchment inventories of trace metals in soils and sediments in mountain lake catchments in the Central Pyrenees: apportioning the anthropogenic and natural contributions. Geochim Cosmochim Acta 82:52-67

Brahney J, Mahowald N, Ward DS, Ballantyne AP, Neff JCCGB (2015) Is atmospheric phosphorus pollution altering global alpine lake stoichiometry? Glob Biogeochem Cycles 29:1369-1383

Camarero L (2003) Spreading of trace metals and metalloids pollution in lake sediments over the Pyrenees. J Phys IV France 107:249-253

Camarero L, Botev I, Muri G, Psenner R, Rose N, Stuchlik E (2009) Trace elements in alpine and arctic lake sediments as a record of diffuse atmospheric contamination across Europe. Freshw Biol 54:2518-2532

Camarero L, Catalan J (1996) Variability in the chemistry of precipitation in the Pyrenees (northeastern Spain): dominance of storm origin and lack of altitude influence. J Geophys Res 101:29491-29498

Camarero L, Catalan J (1998) A simple model of regional acidification for high mountain lakes: application to the Pyrenean lakes (North-East Spain). Water Res 32:1126-1136

Camarero L, Catalan J (2012) Atmospheric phosphorus deposition may cause lakes to revert from phosphorus limitation back to nitrogen limitation. Nat Commun 3:1118

Camarero L, Masqué P, Devos W, Ani-Ragolta I, Catalan J, Moor HC, Pla S, Sanchez-Cabeza JA (1998) Historical variations in lead fluxes in the Pyrenees (NE Spain) from a dated lake sediment core. Water Air Soil Pollut 105:439-449

Cowling EB (1982) Acid precipitation in historical perspective. Envir Sci Technol 16:A110-A123

EEA (2013) EU emissions of As, Cd, Hg, Ni and Pb, 2002-2011, as a percentage of 2002 emissions. http://www.eea.europa.eu/data-and-maps/figures/eu-emissions-of-as-cd-1

Elser JJ (2011) World Awash Nitrogen Sci 334:1504-1505

Galloway JN, Dentener FJ, Capone DG, Boyer EW, Howarth RW, Seitzinger SP, Asner GP, Cleveland CC, Green PA, Holland EA, Karl DM, Michaels AF, Porter JH, Townsend AR, Vöosmarty CJ (2004) Nitrogen cycles: past, present, and future. Biogeochemistry 70:153-226

Galloway JN, Townsend AR, Erisman JW, Bekunda M, Cai Z, Freney JR, Martinelli LA, Seitzinger SP, Sutton MA (2008) Transformation of the nitrogen cycle: recent trends, questions, and potential solutions. Science 320:889-892

Goldman CR (1988) Primary productivity, nutrients, and transparency during the early onset of eutrophication in ultra-oligotrophic Lake Tahoe, California-Nevada. Limnol Oceanogr 33:1321-1333

Gorham E, Underwood JK, Martin FB, Gordon O (1986) Natural and anthropogenic causes of lake acidification in Nova Scotia. Nature 324:451-453

Klaminder J, Hammarlund D, Kokfelt U, Vonk JE, Bigler C (2010) Lead contamination of subarctic lakes and its response to reduced atmospheric fallout: can the recovery process be counteracted by the ongoing climate change? Environ Sci Technol 44:2335-2340

Likens GE, Bormann FH (1974) Acid rain: a serious regional environmental problem. Science 184:1176-1179

Mahowald N, Jickells TD, Baker AR, Artaxo P, Benitez-Nelson CR, Bergametti G, Bond TC, Chen Y, Cohen DD, Herut B, Kubilay N, Losno R, Luo C, Maenhaut W, McGee KA, Okin GS, Siefert RL, Tsukuda S (2008) Global distribution of atmospheric phosphorus sources, concentrations and deposition rates, and anthropogenic impacts. Glob Biogeochem Cycles 22:GB4026

Mahowald NM, Kloster S, Engelstaedter S, Moore JK, Mukhopadhyay S, McConnell JR, Albani S, Doney SC, Bhattacharya A, Curran MAJ, Flanner MG, Hoffman FM, Lawrence DM, Lindsay K, Mayewski PA, Neff J, Rothenberg D, Thomas E, Thornton PE, Zender CS (2010) Observed 20th century desert dust variability: impact on climate and biogeochemistry. Atmos Chem Phys 10:10875-10893

Moulin C, Lambert CE, Dulac F, Dayan U (1997) Control of atmospheric export of dust from North Africa by the North Atlantic oscillation. Nature 387:691-694

Neary BP, Dillon PJ (1988) Effects of sulphur deposition on lake water chemistry in Ontario. Nature 333:340-343 
Needleman H (2004) Lead poisoning. Annu Rev Med 55:209-222

Nriagu JO (1996) A history of global metal pollution. Science 272:223-224

Nriagu JO, Wong HKT, Lawson G, Daniel P (1998) Saturation of ecosystems with toxic metals in Sudbury basin, Ontario, Canada. Sci Total Environ 223:99-117

Odén S, Ahl T (1979) The acidification of Scandinavian lakes and rivers. Ymer, Årsbok

Pitelka LF, Raynal DJ (1989) Forest decline and acidic deposition. Ecology 70:2-10

Psenner R (1999) Living in a dusty world: airborne dust as a key factor for alpine lakes. Water Air Soil Pollut 112:217-227

Schindler DW, Mills KH, Malley DF, Findlay DL, Shearer JA, Davies IJ, Turner MA, Linsey GA, Cruikshank DR (1985) Long-term ecosystem stress: the effects of years of acidification on a small lake. Sci (WashDC) 228:1395-1401

Smith RA (1872) Air and rain: the begginings of a chemical climatology. Longmans Green, London

Smith SJ, van Aardenne J, Klimont Z, Andres RJ, Volke A, Delgado Arias S (2011) Anthropogenic sulfur dioxide emissions: 1850-2005. Atmos Chem Phys 11:1101-1116

Stoddard JL, Traaen T (1995) The stages of nitrogen saturation: Classification of catchments included in 'ICP on Waters'. In: Hornung M, Sutton MA, Wilson RB (eds) Mapping and modelling of critical loads for nitrogen, Proceedings of the grange-over-sands workshop, 2426 Oct 1994. Institute of Terrestrial Ecology, Edinburg, pp 55-62.I

Streets DG, Waldhoff ST (2000) Present and future emissions of air pollutants in China: $\mathrm{SO}_{2}$, NOx, and CO. Atmos Environ 34:363-374

Sullivan TJ, Eilers JM, Church MR, Blick DJ, Eshleman KN, Landers DH, DeHaan MS (1988) Atmospheric wet sulphate deposition and lakewater chemistry. Nature 331:607-609

UNECE (2016a) The 1979 Geneva Convention on Long-range Transboundary Air Pollution. http://www.unece.org/env/lrtap/lrtap_h1.html, http://www.unece.org/env/lrtap/lrtap_h1.html. 2016

UNECE (2016b) The 1998 Aarhus Protocol on Heavy Metals. http://www.unece.org/env/lrtap/ hm_h1.html

Wang R, Balkanski Y, Boucher O, Ciais P, Penuelas J, Tao S (2015) Significant contribution of combustion-related emissions to the atmospheric phosphorus budget. Nat Geosci 8:48-54

Wright RF, Aherne J, Bishop K, Camarero L, Cosby BJ, Erlandsson M, Evans CD, Forsius M, Hardekopf DW, Helliwell R, Hruska J, Jenkins A, Kopacek J, Moldan F, Posch M, Rogora M (2006) Modelling the effect of climate change on recovery of acidified freshwaters: relative sensitivity of individual processes in the magic model. Sci Total Environ 365:154-166

Wright RF, Larssen T, Camarero L, Cosby BJ, Ferrier RC, Helliwell R, Forsius M, Jenkins A, Kopacek J, Majer V, Moldan F, Posch M, Rogora M, Schöpp W (2005) Recovery of acidified European surface waters. Environ Sci Technol 39:64A-72A

Open Access This chapter is licensed under the terms of the Creative Commons Attribution 4.0 International License (http://creativecommons.org/licenses/by/4.0/), which permits use, sharing, adaptation, distribution and reproduction in any medium or format, as long as you give appropriate credit to the original author(s) and the source, provide a link to the Creative Commons license and indicate if changes were made.

The images or other third party material in this chapter are included in the chapter's Creative Commons license, unless indicated otherwise in a credit line to the material. If material is not included in the chapter's Creative Commons license and your intended use is not permitted by statutory regulation or exceeds the permitted use, you will need to obtain permission directly from the copyright holder.

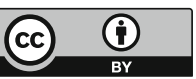

